\title{
Best Practises for Dental Clinics during Covid-19: Guidelines for Practitioners
}

\author{
Batra $\mathrm{P}^{1}$ and Miglani $\mathrm{S}^{2 *}$ \\ ${ }^{1}$ Department of Orthodontics, Jamia Millia Islamia, India \\ ${ }^{2}$ Department of Conservative Dentistry and Endodontics, Jamia Millia Islamia, India
}

*Corresponding author: Sanjay Miglani, Professor, Department of Conservative Dentistry and Endodontics, Jamia Millia Islamia, New Delhi-25, India, Email: smiglani@jmi.ac.in

\section{Review Article}

Volume 5 Issue 3

Received Date: June 11, 2020

Published Date: June 24, 2020

DOI: $10.23880 /$ oajds-16000258

\section{Abstract}

In the last twenty years, this is the third time that viruses have created havoc. Severe Acute Respiratory Syndrome (SARS) in 2003, Middle Eastern Respiratory Syndrome (MERS) in 2014, and COVID-19 in 2019. Such diseases have made the routine functioning challenging and have imposed restrictions on many health services due to the high chances of transmission of disease. The dentists, work in proximity to the mouth of the patient which is the prime source of droplet transmitted infection and since many dental procedures lead to aerosol generation, the safety of the dental surgeon and staff is a matter of concern. Since many patients of COVID-19 are asymptomatic, they can be a potential source of infection, making the situation grave. This article highlights some important steps that should be taken care of by dental practitioners before opening the clinics after the lockdown, during treating patients, and after rendering treatment. Some disinfection protocols, patient triaging, medications, use of PPE's and protocols for patients and doctors to make dental services safe are suggested. The level of precautions or restrictions while practicing dentistry can be relaxed as per the state advisories and when the statistics of infected patients in the region where you practice reduces. Though there is so much information available online and through social communication platforms, the reader can get confused. This article attempts to summarise the key points crucial for practitioners, who are sometimes also the bread earners of the family, based on current scientific evidence, thus practicing safe dentistry.

Keywords: COVID-19; SARS-CoV-2; Dentistry; Dental practitioners; 2019-nCoV

Abbreviations: SARS: Severe Acute Respiratory Syndrome; MERS: Middle Eastern Respiratory Syndrome; PPPE: Procure Personal Protective Equipment; ISHRAE: Indian Society of Heating Refrigerating and Air Conditioner Engineers; AIIMS: All India Institute of Medical Sciences; NSAIDs: Non-Steroidal Anti-Inflammatory Drugs; SDCEP: Scottish Dental Clinical Effectiveness Programme.

\section{Introduction}

COVID 19 is a viral infection caused by novel coronavirus (SARS-CoV-2) which spreads primarily by respiratory droplets expelled during coughing, sneezing, or breathing and through contact routes and digestive tract [1-3]. Nose, mouth, conjunctiva of the eye, ears all have been reported as possible entry points for the virus [4]. This disease has been declared a pandemic by WHO. This disease usually has flu-like symptoms like fever, dry cough, sore throat, pink eyes, and fatigue [5]. It can be accompanied by gastrointestinal symptoms like diarrhoea, nausea and vomiting, and neurological symptoms. The spread of this disease varies in different countries [6]. Affected persons can also be asymptomatic but can be a potential source of infection as they could release a large number of viruses in the early stage of infection $[7,8]$. India also has a large number of asymptomatic adults and children which makes 
the situation even more dangerous [9]. Healthcare workers and dentists are at high risk of catching and transmitting this infection [10]. If the treatment procedures involve the aerosol generation, these aerosols can be a potential source of infection [11]. Due to these factors dentists are in a state of fear and anxiety since the procedures involve proximity to patients [12]. Though there is a lot of information available on this disease, which are revised very frequently, one can get lost reading them [13-16]. The purpose of this article is to summarise the important points for dental practitioners for both operating large and small clinics. These tips will be handy for the practitioners to reduce the chances of getting infected or transmitting infection, thus practicing safe dentistry. The level of precautions or restrictions while practicing dentistry can be relaxed or modified as per the latest state advisories [17-19].

\begin{tabular}{|c|c|c|}
\hline 1 & $\begin{array}{c}\text { Apps installed: Apps for COVID information, Patient } \\
\text { communication }\end{array}$ & Ventilation and Filters \\
\hline 2 & Minimise non- essential items, cover rest with disposable plastics \\
\hline 3 & Procure PPE's, Tissue papers, disinfectants & \\
\hline 4 & Covered Bins & \\
\hline 5 & Notices and education material in place & \\
\hline 7 & Check/disinfect dental water units, air rotors, compressors & \\
\hline 8 & & Train staff \\
\hline
\end{tabular}

Table 1: Quick Checklist before Opening the Clinics.

\begin{tabular}{|c|c|c|}
\hline Dental Emergencies & Urgent Dental Care & Non-Emergency Treatment \\
\hline Uncontrolled bleeding & $\begin{array}{l}\text { Severe dental pain due to any reason like: pulpal } \\
\text { inflammation or caries or pericoronitis or third- } \\
\text { molar pain or tooth fracture or faulty restoration or } \\
\text { orthodontic wire poking in mucosa }\end{array}$ & Periodic oral examinations \\
\hline Space Infections & Dry socket & Routine dental cleaning \\
\hline \multirow{6}{*}{$\begin{array}{l}\text { Trauma to facial bones } \\
\text { compromising airway }\end{array}$} & Abscess & Orthodontic treatment \\
\hline & Avulsion/luxation of tooth & $\begin{array}{c}\text { Restoration of asymptomatic carious } \\
\text { lesion }\end{array}$ \\
\hline & Biopsy of abnormal tissues & Aesthetic dentistry \\
\hline & $\begin{array}{c}\text { Final crown/bridge cementation if the temporary } \\
\text { restoration is lost, broken or causing gingival } \\
\text { irritation }\end{array}$ & \multirow{3}{*}{ Extraction of asymptomatic tooth } \\
\hline & $\begin{array}{c}\text { Dental treatment required prior to critical medical } \\
\text { procedures }\end{array}$ & \\
\hline & $\begin{array}{l}\text { Denture adjustment on radiation/ oncology } \\
\text { patients/ when function impeded }\end{array}$ & \\
\hline
\end{tabular}

Table 2: Categorising Dental Treatment during COVID-19. 


\section{Open Access Journal of Dental Sciences}

\begin{tabular}{|c|c|c|c|}
\hline & Moderate Dental Pain & Severe Pain & Infection \\
\hline \multirow[t]{3}{*}{ Adults } & $\begin{array}{l}\text { Paracetamol, } 2 \times 500 \mathrm{mg} \\
\text { tablets up to four times } \\
\text { daily (i.e. every } 4-6 \\
\text { hours) for } 5 \text { days }\end{array}$ & $\begin{array}{l}\text { Ibuprofen } 3 \times 200 \text { mg tablets up to } \\
\text { four times daily, preferably after } \\
\text { food or diclofenac ( } 1 \text { x } 50 \text { mg tablet } \\
\text { three times daily) and paracetamol } \\
\text { together- not exceeding the } \\
\text { prescribed dose for } 5 \text { days }\end{array}$ & $\begin{array}{l}\text { Acute apical abscess, Acute periodontal } \\
\text { abscess/perio-endo lesions: }\end{array}$ \\
\hline & & $\begin{array}{l}\text { Maximum dose in } 24 \text { hours: } 4 \mathrm{~g} \\
\text { paracetamol; } 2.4 \mathrm{~g} \text { ibuprofen; } 150 \\
\text { mg diclofenac }\end{array}$ & $\begin{array}{l}\text { 5-day course of amoxicillin, } \\
\text { phenoxymethylpenicillin or metronidazole } \\
\text { amoxicillin, } 1 \text { x } 500 \mathrm{mg} \text { capsule } 3 \text { times daily, } \\
\text { or - phenoxymethylpenicillin, } 2 \times 250 \mathrm{mg} \\
\text { tablets } 4 \text { times daily, or - metronidazole, } 1 \mathrm{x} \\
400 \mathrm{mg} \text { tablet } 3 \text { times daily. }\end{array}$ \\
\hline & & & $\begin{array}{l}\text { Acute pericoronitis, Necrotising ulcerative } \\
\text { gingivitis/periodontitis: 3-day course of } \\
\text { metronidazole or amoxicillin. }\end{array}$ \\
\hline \multirow[t]{2}{*}{ Children } & \multicolumn{2}{|c|}{$\begin{array}{l}\text { Paracetamol } 500 \mathrm{mg} \text { tablets, or } 120 \mathrm{mg} / 5 \mathrm{ml} \text { or } 250 \mathrm{mg} / 5 \mathrm{ml} \\
\text { oral suspension, dose depending on age or ibuprofen } 200 \mathrm{mg} \\
\text { tablets or } 100 \mathrm{mg} / 5 \mathrm{ml} \text { oral suspension, dose depending on } \\
\text { age any of the above for } 5 \text { days max } 4 \text { doses }\end{array}$} & $\begin{array}{c}\text { Mild infection: amoxicillin (250 } \\
\text { mg capsules, or Oral Suspension* } \\
125 \mathrm{mg} / 5 \mathrm{ml} \text { or } 250 \mathrm{mg} / 5 \mathrm{ml}) \text { dose } \\
\text { depending on age ; three times daily, Or } \\
\text { phenoxymethylpenicillin }(250 \mathrm{mg} \text { tablets, } \\
\text { or Oral Solution*, } 125 \mathrm{mg} / 5 \mathrm{ml} \text { or } 250 \mathrm{mg} / 5 \\
\text { ml) dose depending on age (see below); } \\
\text { four times daily, Or metronidazole }(200 \mathrm{mg} \\
\text { tablets, or Oral Suspension, } 200 \mathrm{mg} / 5 \mathrm{ml}) \\
\text { dose depending on age (see below) three } \\
\text { times daily unless indicated below }\end{array}$ \\
\hline & & & $\begin{array}{c}\text { Severe infection: Children aged } 6 \\
\text { months to } 11 \text { years, amoxicillin up to } 30 \\
\mathrm{mg} / \mathrm{kg} \text { (max } 1 \mathrm{~g} \text { ) three times daily } \mathrm{Or} \\
\text { phenoxymethylpenicillin up to } 12.5 \mathrm{mg} / \\
\text { kg four times daily. Children aged } 12-17 \\
\text { years, double the dose of amoxicillin or } \\
\text { phenoxymethylpenicillin up to } 1 \mathrm{~g} \text { four times } \\
\text { daily }\end{array}$ \\
\hline
\end{tabular}

Table 3: Recommended Analgesics and Antibiotics during COVID-19.

\section{Opening Clinics Post Lockdown}

Since the clinics would be locked for long, these small points need to be taken care of:

a) Dental unit waterlines and suctions, spittoons should be flushed with a biocide to remove any biofilms that might have developed [20].

b) Lubricate and autoclave the air motors and hand pieces

c) Prepare compressors and check for the desired pressure build-up according to the manufacturer. Equipment powered by air compressor like 3 -in- 1 syringes etc. should be avoided.

d) Inform your patients about the changed methods of functioning of your dental clinic, including consultations from phone, videoconference, appointments, and medications.

e) Place notices on the clinic door regarding changed functioning and telemedicine.

f) Make your clinics especially practicing room with minimum furniture or materials like carpets, curtains, toys, magazines which are difficult to clean or to reduce touchable.

g) Prepare your clinics for contactless deliveries of materials and medicine

h) Keep surface disinfectant handy so that all the materials delivered are first disinfected.

i) Train the staff on how to collect and disinfect deliverables.

j) Procure personal protective equipment (PPE) for clinicians, staff, and attendants of young children, who cannot visit unescorted. 
k) Ventilation, the clinics should be made as ventilated as possible by keeping all doors and windows open. However, if possible designate a particular area/room for aerosol-generating procedures where the door should remain shut [21]. According to the guidelines compiled by the Indian Society of Heating Refrigerating and Air Conditioner Engineers (ISHRAE) a temperature of 24$300 \mathrm{C}$ should be maintained for Air conditioners [22,23]. However centralized ACs in big hospitals can have high chances of virus circulating in the air due to recirculation of the same air, so appropriate filtration (like HEPA) would be required. Fans increase the circulation of air, also, a slight negative or neutral pressure in the room will increase the air circulation per hour thus providing fresh air and removing pathogens. Since the equipment for creating negative pressure are expensive, an exhaust fan can be installed to exhaust air for better ventilation [22]. Also, the airflow should be from clean areas to less clean areas. So, the best way for a single room with stand-alone AC would be switching the fan (preferably a pedestal) on with AC and exhaust and partially open window (for a fresh source of air). If due to any reason exhaust fan cannot be installed, filtration of air with HEPA filters should be done [22].

l) Use portable air purifiers having HEPA filters as they can remove particles of the dimension of aerosols [24]. These HEPA filters shall be a minimum of H13 (EN18221) filter class or equivalent [22]. Coronavirus has a size of $60-140 \mathrm{~nm}$ and these filters should are $99.7 \%$ efficient in removing particles of 0.3 microns in diameter. All the filters should be disinfected to prevent secondary contamination after wearing proper PPE's.

m) Install apps (COVID watch, Aarogya setu etc.) so that you can check the zone from where the patient, consultant or staff is coming [25].

n) Cover the computers with physical barriers like disposable covers or plastics.

o) Arrange for tissue papers and properly covered bins for disposal of used tissues.

p) Put patient education material on walls regarding hand hygiene and sneezing etiquettes.

q) Equip the clinic for paperless documentation and communicate to the patient with messages or apps.

\begin{tabular}{|c|c|}
\hline \multirow{13}{*}{ Air disinfection } & After non-aerosol generating procedures \\
\hline & Negative pressure room: Leave for $15 \mathrm{~min}$ \\
\hline & Neutral pressure room: Leave for 30 minutes** \\
\hline & After aerosol generating procedures \\
\hline & Negative pressure room: Leave for $20 \mathrm{~min}$ \\
\hline & Neutral pressure room: Leave for 60 minutes** \\
\hline & Adjuncts for both procedures \\
\hline & UV-C: $20-30 \min ^{* * *}$ \\
\hline & HEPA Filter: HEPA 13 or more \\
\hline & Extraoral suctions can reduce aerosols. \\
\hline & Disinfection fogging: Hydrogen Peroxide or Chlorine dioxide for 60 minutes. \\
\hline & $\begin{array}{l}{ }^{* *} \text { Air changes may be boosted with use of exhaust fan and pedestal fans. The air flow } \\
\text { should be from clean areas to less clean areas. A minimum of } 6 \mathrm{ACH} \text { is acceptable. }\end{array}$ \\
\hline & $\begin{array}{l}\text { *** The UV_C }(200-350 \mathrm{~nm}) \text { light should be place in such a way that it should reach all } \\
\text { areas of operatory. The wattage may differ as per the size of room and manufacturer's } \\
\text { instruction. It is advisable to use UV-C overnight in the clinic. }\end{array}$ \\
\hline
\end{tabular}




\begin{tabular}{|c|c|}
\hline \multirow{8}{*}{ Surface disinfection } & $\begin{array}{l}\text { Floor should be cleaned with a damp mop floor with three bucket technique-Water, } \\
\text { Detergent \& Low-level Disinfectant, 1\% sodium hypochlorite or EPA approved agents. }\end{array}$ \\
\hline & $\begin{array}{l}\text { Frequently touched clinical surfaces within } 3 \text { feet diameter of the dental chair } \\
\text { should either be covered using a physical barrier or disinfected between patients } \\
\text { using a wipe (E.g. 1\% sodium hypochlorite or } 70 \% \text { alcohol for sensitive surfaces) }\end{array}$ \\
\hline & $\begin{array}{l}\text { Wet dust all non- critical/ non touch surfaces horizontal, vertical surfaces with } \\
\text { freshly prepared disinfectant solution once a day unless visibly soiled with a cotton } \\
\text { cloth (or microfiber) (E.g. 1\% Sodium hypochlorite or } 3 \% \text { hydrogen peroxide) }\end{array}$ \\
\hline & $\begin{array}{l}\text { Walls, window blinds, frames cleaned and disinfected when visibly soiled or end of } \\
\text { the day }\end{array}$ \\
\hline & $\begin{array}{l}\text { Mop heads and cleaning cloths must be discarded in biomedical waste bins } \\
\text { appropriates or decontaminated regularly by laundering (heat disinfection) with } \\
\text { detergent, 1:1000 dilution of sodium hypochlorite and drying upside down. }\end{array}$ \\
\hline & $\begin{array}{l}\text { Vacuum cleaners with HEPA filters should be used, when vacuum cleaning is } \\
\text { necessary. }\end{array}$ \\
\hline & $\begin{array}{c}\text { 1: } 100 \text { dilution of 5.25- } 6.15 \% \text { i.e., } 0.01 \% \text { of sodium hypochlorite may be used for } \\
\text { Dental Unit Waterline/suctions }\end{array}$ \\
\hline & The house keeping staff must wear recommended PPE \\
\hline \multirow[b]{2}{*}{$\begin{array}{l}\text { Toilets (due to suspected faeco- } \\
\text { oral transmission) }\end{array}$} & Have good ventilation \\
\hline & $\begin{array}{c}\text { Disinfection with freshly prepared } 1 \% \text { sodium Hypochlorite/ detergent. } 70 \% \text { Alcohol } \\
\text { may be used to clean the surfaces where the use of bleach is not suitable. Do not spray } \\
\text { disinfectants on highly contaminated areas like toilet bowl as it can create splashes, } \\
\text { which may lead to further spread the virus. }\end{array}$ \\
\hline $\begin{array}{l}\text { Patient Care Items and Devices } \\
\text { (such as surgical instruments, } \\
\text { scalers, or those penetrating soft } \\
\text { tissue/ bone, mouth mirrors, } \\
\text { amalgam condensers, reusable } \\
\text { dental impression trays and } \\
\text { handpieces) }\end{array}$ & $\begin{array}{l}\text { Steam sterilisations or heat-tolerant instruments or disposable alternatives. Gross } \\
\text { soil (e.g. Mucous, saliva, and blood) should be removed immediately at point-of-use. } \\
\text { If cleaning cannot be done immediately, the medical equipment/device must be } \\
\text { submerged in tepid water and detergent or enzymatic cleaner to prevent organic } \\
\text { matter from drying on it. }\end{array}$ \\
\hline
\end{tabular}

Table 4: Disinfection Protocol for Dental Clinics during COVID-19.

\section{Which Patients to Call and which to Defer (Patient triage)?}

Since there are many asymptomatic patients it will be safe to consider every patient as a potential source of infection for COVID-19. The patient can be afebrile or undetected for COVID-19. Keeping these points in mind the following precautions can be taken:

a) Sort the patients before they report to the clinic.

b) Telephonically manage the patients, if possible, practice teledentistry.

c) Categorize the treatment needed into 3 categories. ADA or similar state guidelines can be followed (Table 2) [26].

d) If the patient falls under the emergency or urgent category, first check the zone from which the patient is coming by Aarogya Setu app [25]

e) No accompanying person should be entertained except in pediatric patients. The basic idea is to minimize the footfall in the clinic.

f) If you opt to call regular patients all the precautions mentioned should be followed. You can decide on this based on state advisories for COVID-19.

\section{How to Schedule Appointments}

If the patients fall in the emergency or urgent category the appointments should be scheduled in such a way that there is attest an hour gap between the appointments. During this gap, one would disinfect the clinic and prepare the clinic for the other patient as described below. Also if there is any aerosol-generating procedure that has been done like making cavities or scaling with ultrasonic scaler the aerosols would settle in $30 \mathrm{~min}$ if the room is properly ventilated but can remain for several hours in still air 


\section{Open Access Journal of Dental Sciences}

$[27,28]$. Thus a one hour gap will give time for the aerosols to settle and will also enable a minimum of 6 air circulations per hour. Though to be on the safer side we can demarcate or limit aerosol-generating procedures to one part of the clinic. However, it has been documented that aerosols can travel up to 10 meters so it would be wise to limit aerosol-generating procedures to a single room in a multiple room dental setting $[29,30]$. Hence even if you have multiple chairs in your clinic that strategy of working on alternate chairs cannot be fully justified. So multiple patients can be seen only if you have multiple rooms in your clinic rather than multiple chairs.

\section{How to Take Payments}

The coronavirus has been found to survive for different periods depending on the surface, for example, $72 \mathrm{hrs}$ on plastic surfaces, $48 \mathrm{hrs}$ on stainless steel, and $24 \mathrm{hrs}$ on cardboard [31]. It has been found that viruses like the human influenza virus can survive for several days on banknotes [32]. The study also warned that in case of pandemic events, the banknotes could be the possible mode of transmission of viruses. In wake of this pandemic IIT Bombay has developed a portable UV sanitizer to disinfect currency, mobiles and purses [33]. Thus the probability of COVID 19 spreading through currency notes cannot be negated. Keeping this in view and the fact that currency comes in hand contact of many, it would be safe to avoid currency or card transaction in the dental clinic. Unified Payment Interface (UPI) applications e.g. BHIM UPI, Phone Pe, Paytm, Google Pay, etc. should be preferred as alternative modes of payment. This would also negate the need for coming in proximity while carrying out the transactions.

\section{How Does the Patient Enter Clinic-Some Precautions that can be Taken to Avoid Transmission of Disease are as Follows}

a) Adult patients should not be accompanied by anyone if it is required the accompanying person should stay outside the clinic or in his car to avoid crowding.

b) Hand sanitizer or soap should be kept handy at the reception. When using soap it should be preferable in an automatic dispenser and taps with sensors should be preferred so that the patient does not touch any surface. If the clinic is not equipped with either, then the taps should also be washed with soap at the end of washing hands. In such cases, hand sanitizers with more than $70 \%$ alcohol preferably ethanol should be used [34].

c) If the patient is wearing his own mask, it should be left outside the clinic in a bag which he can collect later, and fresh masks should be given before entering the clinic.

d) The doors should preferably be left open so that minimum surface contact is there like on the door handles or at reception.

e) If possible, the patients should not be allowed to wait in the waiting area, or waiting period should be kept to a minimum. If that is not possible, patients should wear their masks and practice social distancing in the waiting room.

f) They should have talked to the receptionist before only and should directly reach the clinician.

g) The patient should wear shoe covers before entering the clinics.

h) If the patient is a child or a dependant patient, the accompanying persons should wait outside the clinic if possible.

\section{How Does the Consultant Enter Operatory: The Sequence of Wearing and Removing PPE's}

A specific area can be designated in the operatory as a PPE wearing and removing area. The PPEs should be worn in such a way that no part of the skin, eyes, ears, mouth, or underclothes are left exposed. The sequence of wearing the PPEs is as follows:

- Wash hands

- Head caps

- Shoe covers

- Gowns

- Masks/respirators

- Goggles

- Face shield

- Gloves [35]

Polyethylene-coated water repellent disposable gowns (isolation gowns) with zippers or similar are advocated for airborne pathogens. A medium gown of 70gsm should be enough for dentists [36]. The design of the gown, size, fit, and fabric all determine the amount of protection they provide [37]. In general, since dentistry involves the aerosol generation and sometimes saliva or blood splatter, so disposable gowns are preferred. However, a clinician can wear a fabric gown during non-aerosol or simple procedures where blood and saliva splatter is not anticipated. Though fabric gowns will have to be safely removed and washed at $60-90^{\circ} \mathrm{C}$ with detergent and later soaked in $0.05 \%$ chlorine for 30 minutes as per WHO guidelines. After disinfecting they should be rinsed again with clean water and dried fully in sunlight. Surgical masks that one usually uses are not enough to protect against coronavirus. N-95/FFP2 masks also called respirators are ideally required. These respirators are available in various sizes so they should be fit checked before they are worn otherwise the whole purpose is defeated [38]. These N-95 masks are expensive respirators. UV C chambers/ UV-C lamp sterilization equipment or hydrogen peroxide if 


\section{Open Access Journal of Dental Sciences}

available may be used to disinfect and reuse the mask for 5-10 times depending on the aerosol load and duration of wear [39]. Another simple way is to keep it in open for 5 days, as suggested by All India Institute of Medical Sciences (AIIMS) since the virus will die off on its own without a host but this has not been scientifically proved [40].

Once the procedure is finished all the PPES should be removed in that designated area inside operatory except the mask/respirator which is removed after leaving the operating room. The sequence for removing the PPES is as follows:

- Gown

- Gloves

- Face shield

- Goggles

- Mask (remove after leaving the operating room)

- Wash hands [35]

The recommended sequence of wearing and removing PPE can found at https://www.cdc.gov/hai/pdfs/ppe/ppesequence.pdf. Dispose of the gowns and gloves in covered biohazard dustbin for disinfection.

\section{Staff Considerations}

One should have bare minimum staff in the clinic so that social distancing can be followed and at the same time proper sterilization and infection control measures can be carried out. The receptionists should be trained in patient triaging and scheduling appointments. All the staff should be trained in the correct method of PPE wearing and removal, should be aware of sneezing etiquettes, should follow hand hygiene, and should avoid touching many areas. It is better to avoid the footfall of medical representatives and dental suppliers and means of contactless deliveries should be adopted. The staff should also be trained in how the deliverables are collected and disinfected before getting into the clinic. Also, one must make a note of the zone/region from where the staff is coming. Essential PPES should be provided to the assistants also in the operatory.

\section{Precautions to be Taken while Treating the Patients}

The patient is advised to do a mouth rinse before any procedure with oxidative agents such as $1 \%$ hydrogen peroxide or $0.2 \%$ povidone for 15 seconds to reduce the microbial load. Chlorhexidine may not be effective against $\mathrm{nCoV}$ [10]. Apart from droplets as a source of transmission, the aerosols generated during procedures like scaling and cavity preparation could also be a potential source of transmission. Hence it is advised to either avoid aerosol producing procedures or keep aerosol-generating procedures confined to one place with doors closed and proper ventilation and filtration measures adopted as mentioned above.

Aerosols are generated maximum during ultrasonic and sonic scaling and to a lesser extent during cavity preparation [27]. The use of high-volume suctions and rubber dams where possible is advocated to reduce the aerosols generated [41]. If hand scaling is possible it should be preferred. Antiretraction high-speed hand pieces are advocated to reduce the backflow of pathogens into the air and water tubes [42]. Slow hand pieces with irrigation are advocated for bone removal. Extraoral suctions may also be used as an adjunct to reduce aerosols. For suspected/confirmed cases of COVID-19, all the PPEs should be worn, and all the abovementioned precautions should be taken $[43,44]$. If possible, mechanical ventilation of room should commence before treating the next patient. If a patient has previously tested positive for COVID-19 infection and 3 days have passed since symptoms have resolved, the patient can be seen in a dental setting.

\section{Radiographs Which to be Taken, Which to be Avoided}

Intraoral radiography is an important tool in dentistry. Since some intraoral radiographs like IOPA's might induce coughing and increase the saliva secretion so they should be avoided $[45,46]$. If possible only extraoral radiographs like OPG or CBCT should be used. Since these are expensive and all dental clinics may not be equipped with them, the patient may be referred to the nearest diagnostic center or WHO guidelines of personal protection should be administered while taking them.

\section{Analgesics and Antibiotics}

Visit of patients with mild to moderate pain to the clinic can be deferred, prescribing analgesics and antimicrobials via telemedicine is advisable. Patient's medical history, personal history (allergies, pregnancy, age of the patient, etc) common drug interactions should be kept in mind while prescribing medicines since during this pandemic the patients may require medications for a longer time till fully functional dental services are enabled. There are certain reports raising concerns about the use of non-steroidal anti-inflammatory drugs (NSAIDs) and corticosteroids in COVID-19 patients. However, they have not been scientifically conclusive [47]. Hence, paracetamol should be preferred over ibuprofen in COVID-19 confirmed or suspected cases. The Scottish Dental Clinical Effectiveness Programme (SDCEP) recommended analgesics and antibiotics are mentioned in Table 3 [48].

\section{Disinfection in between Appointments}

Since the aerosols would take around half an hour to 
settle, and 6 air circulations per hour would take a minimum of one hour, so the appointments should be scheduled at a gap of an hour at least unless one has a clinic with multiple rooms. The disinfection protocols that should be carried out during this time to prevent transmission of disease are summarised in Table 4 [49-58]. 1\% sodium hypochlorite solution can be prepared as mentioned in Table 5 [51].

\begin{tabular}{|c|c|c|}
\hline Product & Available chlorine & 1percent \\
\hline Sodium hypochlorite - liquid bleach & $3.50 \%$ & 1 part bleach to 2.5 parts water \\
\hline Sodium hypochlorite - liquid & $5 \%$ & 1 part bleach to 4 parts water \\
\hline NaDCC powder & \multirow{2}{*}{$60 \%$} & \multirow{2}{*}{17 grams to 1 litre water } \\
\hline (sodium dichloroisocyanurate) & & \\
\hline NaDCC $(1.5 \mathrm{~g} /$ tablet $)$ - tablets & $60 \%$ & 11 tablets to 1 litre water \\
\hline Chloramine - powder & $25 \%$ & $80 \mathrm{~g}$ to 1 litre water \\
\hline Bleaching powder & $70 \%$ & $7 \mathrm{~g} \mathrm{~g}$ to 1 litre water \\
\hline
\end{tabular}

Table 5: Method of Preparing 1\% Sodium Hypochlorite [51].

\section{How to Return Home}

It is important to take all precautions so that you don't carry the infection home, hence, change from scrubs to your clothing in a room outside the operatory. Wash hands just before leaving cleaning, remove the shoes outside your house, wash hands, and take shower after reaching home.

\section{Conclusion}

\section{How can we be better prepared for the future?}

This is the third time in twenty years that viruses have caused havoc. Severe Acute Respiratory Syndrome (SARS) in 2003, Middle Eastern Respiratory Syndrome (MERS) in 2014, and COVID-19 in 2019. This should be taken as a lesson and all the changes in designing and ventilation of the clinic and steps like installation of soap dispensers and taps with sensors should be done as soon as circumstances permit to minimize the transmission of infection.COVID-19 pandemic has changed the way we looked at the world. It has medical, social, and economic impacts on all spheres of life including dentistry. Though at present, dentistry will not be practiced as before, in our opinion, it will become better, bigger, and safer with time.

\section{References}

1. Gorbalenya AE, Baker SC, Baric RS, Groot RJ, Drosten C, et al. (2020) Severe acute respiratory syndrome-related coronavirus-The species and its viruses, a statement of the Coronavirus Study Group. BioRxiv.

2. Otter JA, Donskey C, Yezli S, Douthwaite S, Goldenberg SD, et al. (2016) Transmission of SARS and MERS coronaviruses and influenza virus in healthcare settings: the possible role of dry surface contamination. J Hosp
Infect 92(3): 235-250.

3. Surveillances V (2020) The epidemiological characteristics of an outbreak of 2019 novel coronavirus diseases (COVID-19)-China, 2020. China CDC Weekly 2(8): 113-122.

4. Lu CW, Liu XF, Jia ZF (2020) 2019-nCoV transmission through the ocular surface must not be ignored. Lancet 395(10224): e39.

5. Jiang F, Deng L, Zhang L, Cai Y, Cheung CW, et al. (2020) Review of the Clinical Characteristics of Coronavirus Disease 2019 (COVID-19). J Gen Intern.

6. WHO (2020) Coronavirus disease 2019 (COVID-19) situation report-119.

7. Wang Y, Wang Y, Chen Y, Qin Q (2020) Unique epidemiological and clinical features of the emerging 2019 novel coronavirus pneumonia (COVID-19) implicate special control measures. J Med Virol 92(6): 568-576.

8. Mizumoto K, Kagaya K, Zarebski A, Chowell G (2020) Estimating the asymptomatic proportion of coronavirus disease 2019 (COVID-19) cases on board the Diamond Princess cruise ship, Yokohama, Japan, 2020. Euro Surveill 25(10): 2000180.

9. Balasubramanian S, Rao NM, Goenka A, Roderick M, Ramanan AV (2020) Coronavirus Disease (COVID-19) in Children - What We Know So Far and What We Do Not? Indian Pediatr 57(5): 435-442.

10. Peng X, Xu X, Li Y, Cheng L, Zhou X, et al. (2020) Transmission routes of $2019-\mathrm{nCoV}$ and controls in dental practice. Int J Oral Sci 12(1): 9. 
11. Wax RS, Christian MD (2020) Practical recommendations for critical care and anesthesiology teams caring for novel coronavirus (2019-nCoV) patients. Can J Anaesth 67(5): 568-576.

12. Ahmed MA, Jouhar R, Ahmed N, Adnan S, Aftab M, et al. (2020) Fear and Practice Modifications among Dentists to Combat Novel Coronavirus Disease (COVID-19) Outbreak. Int J Environ Res Public Health 17(8): 2821.

13. American Dental Association (2020) ADA interim guidance for minimizing risk of COVID-19 transmission.

14. CDC Guidance for Providing Dental Care During COVID-19.

15. Chugh R, Chugh V, Lamba A, Shah Y, Mukherjee J, et al. (2020) Protocol-Covid 19. Indian Dental Association

16. Singh R, Dhoble A (2020) Indian Dental Association's Preventive Guidelines for Dental Professionals on the Coronavirus Threat.

17. ADA Dental Service Restrictions in COVID-19.

18. India Fights Corona COVID-19.

19. Revised Guidelines on Clinical Management of COVID-19.

20. Practice Management during COVID-19 Pandemic.

21. Chen C, Zhao B (2020) Makeshift hospitals for COVID-19 patients: where health-care workers and patients need sufficient ventilation for more protection. J Hosp Infect 105(1): 98-99.

22. ISHRAE COVID-19 Guidance Document for Air Conditioning and Ventilation.

23. Covid-19: Government guidelines on ACs, coolers and fans.

24. Elias B, Yam BY (2020) Could Air Filtration Reduce COVID-19 Severity and Spread? New England Complex Systems Institute.

25. Aarogya Setu Mobile App.

26. What constitutes a dental emergency.

27. Bennett AM, Fulford MR, Walker JT, Bradshaw DJ, Martin MV, et al. (2000) Microbial aerosols in general dental practice. Br Dent J 189(12): 664-667.

28. Ong SWX, Tan YK, Chia PY (2020) Air, Surface Environmental, and Personal Protective Equipment Contamination by Severe Acute Respiratory Syndrome Coronavirus 2 (SARS-CoV-2) From a Symptomatic
Patient 323(16): 1610-1612.

29. Setti L, Passarini F, De Gennaro G (2020) Airborne Transmission Route of COVID-19: Why 2 Meters/6 Feet of Inter-Personal Distance Could Not Be Enough. Int J Environ Res Public Health 17(8): 2932.

30. Morawska L, Cao J (2020) Airborne transmission of SARS-CoV-2: The world should face the reality. Environ Int 139: 105730

31. Van Doremalen N, Bushmaker T, Morris DH (2020) Aerosol and surface stability of SARS-CoV-2 as compared with SARS-CoV-1. N Engl J Med 382(16): 1564-1567.

32. Thomas Y, Vogel G, Wunderli W (2008) Survival of influenza virus on banknotes. Appl Environ Microbiol 74(10): 3002-3007.

33. Sanitizing currency notes, mobile phones made easy! IIT Bombay develops portable UV sanitizers.

34. Yan Y, Chen H, Chen L, Cheng B, Diao P, et al. (2020) Consensus of Chinese experts on protection of skin and mucous membrane barrier for healthcare workers fighting against coronavirus disease 2019. Dermatol Ther.

35. Centers for Disease Control and Prevention recommendations for putting on and removing personal protective equipment for treating COVID-19 patients.

36. Medical Gowns.

37. Kilinc FS (2015) A Review of Isolation Gowns in Healthcare: Fabric and Gown Properties. J Eng Fiber Fabr 10(3): 180-190.

38. Filtering out Confusion: Frequently Asked Questions about Respiratory Protection.

39. Mackenzie D (2020) Reuse of N95.

40. Reuse N95 masks four times for 20 days by disinfecting: AIIMS Delhi to healthcare workers.

41. Micik RE, Miller RL, Mazzarella MA, Ryge G (1969) Studies on dental aerobiology. I. Bacterial aerosols generated during dental procedures. J Dent Res 48(1): 49-56.

42. Hu T, Li G, Zuo Y, Zhou X (2007) Risk of hepatitis B virus transmission via dental handpieces and evaluation of an anti-suction device for prevention of transmission. Infect Control Hosp Epidemiol 28(1): 80-82.

43. ADA Interim Guidance for Management of Emergency and Urgent Dental Care. 
Open Access Journal of Dental Sciences

44. Ge ZY, Yang LM, Xia JJ, Fu XH, Zhang YZ (2020) Possible aerosol transmission of COVID-19 and special precautions in dentistry. Journal of Zhejiang UniversityScience B 21: 361-368.

45. World Health Organization (2020) Rational use of personal protective equipment (PPE) for coronavirus disease (COVID-19).

46. Meng L, Hua F, Bian Z (2020) Coronavirus disease 2019 (COVID-19): emerging and future challenges for dental and oral medicine. J Dent Res 99(5): 481-487.

47. Russell B, Moss C, Rigg A, Van Hemelrijck M (2020) COVID-19 and treatment with NSAIDs and corticosteroids: should we be limiting their use in the clinical setting?. Ecancermedicalscience 14: 1023.

48. Drugs for the Management of Dental Problems during COVID-19 Pandemic.

49. Reducing the risk of transmission of COVID-19 in the hospital settings.

50. Guidelines for Infection Control in Dental Health-Care
Settings 2003.

51. Coronavirus Disease 2019 (COVID-19): Standard Operating Procedure (SOP) for transporting a suspect/ confirmed case of COVID-19.

52. Guidelines for Quarantine facilities COVID-19.

53. The national infection prevention and control guidelines for acute healthcare facilities-2017.

54. Standard operating protocol for dental patients during COVID pandemic.

55. COVID-19: Guidelines on disinfection of common public places including offices.

56. Summary of Infection Prevention Practices in Dental Settings.

57. Guidelines on Infection Control Practice in the Clinic Settings of Department of Health.

58. Liu Y, Ning Z, Chen Y, Guo M, Liu Y, et al. Aerodynamic analysis of SARS-CoV-2 in two Wuhan hospitals. Nature. 